\title{
Influência da Nutrição na Reprodução em Suínos
}

Amanda Goldoni ${ }^{1}$, Josiane Schuvank Maculan ${ }^{1}$, Samara de Freitas Oliveira ${ }^{1}$.

${ }^{1}$ Universidade Estadual do Centro-oeste, Campus CEDETEG, Departamento de Medicina Veterinária. Guarapuava,

Paraná. [josianesmaculan@hotmail.com]

ISSUE DOI: $10.3738 / 1982.2278 .1135$

Na suinocultura, muitos fatores contribuem para a eficiência zootécnica e econômica dos planteis, mas não há dúvidas de que a nutrição aliada à reprodução tem um grande impacto na produtividade, tanto das fêmeas quanto dos machos. Os bons resultados na reprodução estão associados à combinação da carga genética dos animais com os diversos efeitos ambientais, dentre eles a nutrição. Qualquer restrição nutricional que interfira com a produção de hormônios de efeito direto na função ovariana, como os hormônios gonadotróficos LH e FSH, tem como consequências, alterações diretas na reprodução. Todas as fases do ciclo reprodutivo da granja estão interligadas, sendo que um erro de manejo nutricional em uma das fases poderá levar a efeitos reprodutivos importantes nas fases seguintes. Em relação às marrãs, sabe-se que sua alimentação influi no crescimento e na idade em que elas iniciarão a vida reprodutiva, tal como no número de óvulos que serão liberados durante os primeiros ciclos estrais; na fase pré-púbere há também impacto direto na taxa de concepção e na mortalidade embrionária. Fêmeas gestantes necessitam manter um estado nutricional adequado e obter nutrientes necessários para assegurar a sobrevivência dos embriões, um maior número de leitões vivos ao parto e um consumo maior de alimentos durante a lactação. Durante a lactação, o objetivo é maximizar a produção de leite e minimizar a perda de peso corporal, para controlar o intervalo desmama-cio e garantir uma taxa de ovulação adequada da fêmea. Em se tratando do reprodutor suíno, problemas de subnutrição na fase pré-púbere geralmente resultam em retardo no desenvolvimento sexual, atraso no atingimento da puberdade, demora no desenvolvimento da genitália externa e consequente supressão da espermatogênese. Vários estudos realizados demonstram que a adição de vitamina A na dieta e uma alimentação equilibrada de energia e proteína, trazem consequências benéficas à reprodução do macho suíno. A relação entre níveis nutricionais e eficiência reprodutiva nos reprodutores tem sido avaliada com base nos parâmetros de biometria testicular, comportamento sexual e produção e qualidade do sêmen.

Palavras-chave: Suinocultura, produtividade, alimentação. 